UDC 667.64:678.026

\title{
INFLUENCE OF 2,4-DIAMINOTOLUENE MODIFIER ON THE PHYSICAL AND MECHANICAL PROPERTIES OF EPOXY COMPOSITE COATINGS
}

\author{
Danylo Stuklyak ; Anna Sapronova ${ }^{2}$; Vitaliy Yatsiyk $^{3}$; Bogdan Gryschuk ${ }^{4}$ \\ ${ }^{1}$ Ternopil Ivan Puluj National Technical University, Ternopil, Ukraine \\ ${ }^{2}$ Kherson State Maritime Academy, Kherson, Ukraine \\ ${ }^{3}$ Ternopil Research Forensic Center of MIA of Ukraine, \\ Ternopil, Ukraine \\ ${ }^{4}$ Ternopil Volodymyr Hnatiuk National Pedagogical University, \\ Ternopil, Ukraine
}

\begin{abstract}
Summary. In the work for the formation of composite material with advanced physical and mechanical properties an epoxy dyanoic oligomer ED-20, a polyethylene polyamine (PEPA) and a modifier of 2,4 diaminotoluenes were used. The dependence of the content of 2,4 - diaminotoluene on the physical and mechanical properties of epoxy composites is studied. For forming a protective coating with advanced cohesive properties, the optimum content of the modifier is $q=1,0$ parts, by which the ability to withstand static, dynamic, and stress shock is increased. The method of the IR-spectral analysis revealed the adsorption and catalytic activity of the modifier, which provides interaction with the side groups of the chain of the epoxy oligomer, which increases the cohesive strength of the materials.
\end{abstract} analysis.

Key words: epoxy composite, destructive bending stresses, elastic modulus, impact strength, IR-spectral

Statement of the problem. To protect the manufacturing equipment, machine parts and mechanisms from wearing, corrosion and temperature changes the polimer protective coatings are used. The world experienced the application of the epoxy composites and protective coatings, created on their basis, owing the complex of advanced properties, welldeveloped raw-materials basis in both Ukraine and other countries. They are used to replace the expansive and valuable materials, as well as to improve the operating properties of the manufacturing equipment. Moreover, available new directions and different fields of the epoxy composites applications caused the higher demands to the operating properties of the epoxy composite materials (CM). One of the ways of solving this problem is the application of new synthesized chemical components, which can affect the structure and, thus, the properties of the developed materials. That is why the creation of new modified materials, possessing the improved complex of operating properties, is one of the main tasks of the material studies [1 - 4].

Analysis of the latest investigations and publications. Nowadays many scientists study the modifiers synthesis for their further application as the materials, which are able to interact with the epoxy oligomers, on the basis of which the operating properties and coatings are improved. The analysis of papers by the authors [5 - 9], in which the manufacturing aspects of forming are presented, as well as the properties of the modified epoxy composites of different purpose application, confirms the effective application of the synthesized chemical admixtures. Application of the diaminotoluenes, easily obtained from the $n$ phenylenediamine by the consequent reactions of diazotization and denitration, when 
nucleophiles are available $3,3^{1}-(1,4$ - phenilene $)$ bis $(2$ - chloropropionitrile $) ; 1,4$ - bis $(\mathrm{N}$, $\mathrm{N}$ diethylcarbonbenzil; 4,4 - methylenebis $(4,1-$ phenylen $)$ bis $(\mathrm{N}, \mathrm{N}-$ dethyldithiocarbonmite); diaminoazobenzene, 2 - methy $1-2$ - thiocyanate -3 (4 thiocyanatephenite) propioamide, containing from 0,01 to 2000 (mas.p), provides the acceleration of the gel-formation, change of the epoxy composite structure, which further provides the improvement of the operating properties of the protective coatings. That is why the application of new chemical admixtures for the improvement of the epoxy protective coating properties is a pressing problem nowadays.

The objective of the paper is to investigate the effect of 2,4 - diaminotoluence modifier on the cohesive properties of the protective epoxy composite coatings.

Materials and the method of investigation. The epoxy dianoic oligomer ED-20 (GOST 10587-84), possessing high adhesion and cohesive strength, unsufficient shrinkage and technological effectiveness being coated on the complex profile surface, was chosen as the main component for the binder while forming the epoxy composite materials (CM).

2,4 - diaminotoluene (DAT) was used as the modifier. The modifier was introduced in the binder, its content being from 0,25 to 2,00 mas.p. for 100 mas.p. of the epoxy oligomer $\mathrm{ED}-20$ (here and below mas.p. is for 100 mas.p. of the epoxy oligomer ED - 20). The molecular formula of the modifier is $\mathrm{C}_{7} \mathrm{H}_{10} \mathrm{~N}_{2}$. The molecular mass of the $2,4-$ diaminotoluene is 122,1677 . The melting temperature is $98^{\circ} \mathrm{C}$. This substance is of the diamine phenylen series. The modifier is solulable in the polar organic diluents - methanole, ethanol, acetone, ethylacetate, low-soluable in water. It is used as the synton for the synthesis of the acridine dye. The modifier structure formula is presented in Fig. 1.

To bind the epoxy composites the hardener polyethylene polyamine PEPA (TY 6-05241-202-78) has been used, which made it possible to harden materials at room temperatures. The PEPA in known to be low-molecular substance, consisting of such interconnected components as $\left[-\mathrm{CH}_{2}-\mathrm{CH}_{2}-\mathrm{NH}-\right]_{\mathrm{n}}$. Different stages of binding were modeled and investigated, the hardener being introduced into the composition at the content of 10 mas.p. on 100 mas.p. of the epoxy oligomer ED - 20 in order to find the maximum components interrelation in the system «binder - modifier» for corresponding properties. The properties of the epoxy dyanoic oligomer, modifier and the hardener are presented on the Table 1.

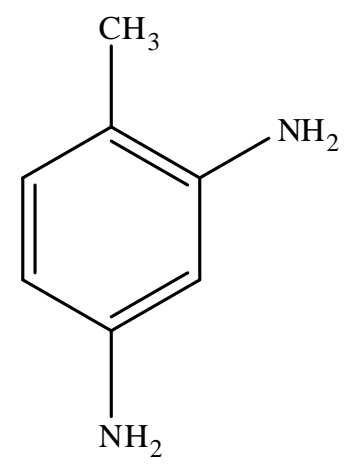

Figure 1. General view of the chemical bonds for the modifier 2,4-diaminotoluene (DAT)

Epoxy composites and coatings based on them were formed in such a way: the resin was heated till $T=353 \pm 2 \mathrm{~K}$, holding time being at this temperature $\tau=20 \pm 0,1 \mathrm{~min}$; the hydrodynamic combining of the oligomer and modifier during the time $\tau=1 \pm 0,1 \mathrm{~min}$, the ultrasound treatment (UST) of the composite during the time $\tau=1,5 \pm 0,1 \mathrm{~min}$, the cooling of the composite to the room temperature during the time $\tau=60 \pm 5 \mathrm{~min}$, the introduction of a hardener and the hydrodynamic combining of the composite components during the time $\tau=5 \pm 0,1 \mathrm{~min}$. The $\mathrm{CM}$ was hardened according to the regime: the specimens forming and 
Influence of 2,4-diaminotoluene modifier on the physical and mechanical properties of epoxy composite coatings

their holding during the time $\tau=12,0 \pm 0,1 \mathrm{~h}$ at the temperature $T=293 \pm 2 \mathrm{~K}$, the heating being with the rate $v=3 \mathrm{~K} / \mathrm{min}$ to the temperature $T=393 \pm 2 \mathrm{~K}$, holding at the temperature $\tau=2,0 \pm 0,05 \mathrm{~h}$, slow cooling till the temperature $T=293 \pm 2 \mathrm{~K}$. In order to stabilize the structural processes in the matrix the specimens were hold during the time $\tau=24 h$ in the air at the temperature $T=293 \pm 2 \mathrm{~K}$ with the further experimental testings being conducted.

Table 1

Epoxy binder components properties

\begin{tabular}{|l|c|c|c|}
\hline \multicolumn{1}{|c|}{ Properties } & $\begin{array}{c}\text { Epoxy oligomer } \\
\text { ED-20 }\end{array}$ & Modifier DAT & Hardener PEPA \\
\hline Molecular mass & $390 \ldots 430$ & 122 & $230 \ldots 250$ \\
\hline Epoxy group content, \% & $20,0 \ldots 22,5$ & - & - \\
\hline Hydroxyl group content, \% & 1,25 & - & - \\
\hline $\begin{array}{l}\text { Average functioning due to epoxy } \\
\text { groups, } f_{n}\end{array}$ & 2,0 & - & - \\
\hline Nitrogen content, \% & - & 22,93 & $19,5 \ldots 22,0$ \\
\hline Carbon content, \% & - & 68,82 & - \\
\hline Hydrogen content, $\%$ & - & 8,25 & - \\
\hline Viscosity, $\eta, P A \cdot s$ & $13 \ldots 20$ & - & 0,9 \\
\hline Density, $\rho, \mathrm{g} / \mathrm{cm}^{3}$ & 1,16 & - & 1,05 \\
\hline
\end{tabular}

In the paper the following CM properties were investigated: destructive stresses and the modulus of elasticity under bending impact strength; the structure of formed composites was investigated taking advantage of the IR-spectral analysis. The distructive bending stresses and the modulus of elasticity were determined according to GOST 4648-71 and GOST 955081 correspondingly. The specimen parameters are: length $l=120 \pm 2 \mathrm{~mm}$, width $b=15 \pm 0,5 \mathrm{~mm}$, height $h=10 \pm 0,5 \mathrm{~mm}$. The impact strength was determined taking advantage of the Sharpy method according to the GOST 4647-80 on the pendulum rod MK 30 at the temperature $T=298 \pm 2 \mathrm{~K}$ and relative humidity $d=50 \pm 5 \%$. The specimens of such parameters were used: $(63,5 \times 12,7 \times 12,7) \pm 0,5 \mathrm{~mm}$. The distance between the mountings being $40 \pm 0,5 \mathrm{~mm}$.

The deviation during investigation of the $\mathrm{CM}$ adhesive and physical-mechanical properties values equals $4 \ldots 6 \%$ of the nominal ones.

The analysis of the IR-spectrums was performed due to the Gambert-Berr law, taking into account the values of the transmission intensity $(T, \%)$ and the square $(S)$ of the adsorption bands on the material spectrum. The decoding of the IR-spectrums was performed according to the methods $[10-11]$. The IR-spectrums were recorded, taking advantage of the spectrometer «IRAffinity-1» (Japan) in the areas of the wave numbers $v=400 \ldots 4000 c$ by the single-ray method in the reflected light. The spectrum scanning according to the wave numbers $\lambda^{-1}=v$ was performed on the diagram within $225 \mathrm{~mm}$ in the range of the chosen frequencies. The wave numbers, the transmission intensity, semi-width and the square of the adsorption band were determined taking advantage of the computer software IR solution. The error while finding the wave number is $v= \pm 0,01 \mathrm{~cm}^{-1}$, the accuracy of the pick location is $v= \pm 0,125 \mathrm{~cm}^{-1}$. The photometric accuracy was $\pm 0,2 \%$ at the software control of the slit, investigation duration being $t=10 \mathrm{~s}$. The integration step is $\Delta \lambda=4 \mathrm{~cm}^{-1}$. The IR-spectral analysis of the modified composites with different content of $\mathrm{C}_{7} \mathrm{H}_{10} \mathrm{~N}_{2}$ was performed. The material was preliminary grinded, dried at the temperature $T=373 \pm 2 \mathrm{~K}$ during $t=20 \mathrm{~min}$, mixed in the agate cup with the $\mathrm{KBr}$ powder and further on the hydraulic press with the 
loading $\sigma=20 \mathrm{MPa}$ the specimens were formed with such interrelation: tested material $1 \mathrm{mg}, \mathrm{KBr}-300 \mathrm{mg}$.

Results of investigations and analysis. To provide long-term operation of the modified composites the investigations of the 2,4 - diaminotoluence content effect on the CM physical-mechanical properties were carried out, the effect of the modifier on the destruction bending stresses values, the modulus of elasticity under bending and impact strength in particular. It was determined earlier, that the properties of the epoxy matrix, treated by the ultrasound, are as follows: the modulus of elasticity under bending is $E=2,9 \mathrm{GPa}$, the destructive bending stresses are $\sigma_{32}=48,0 \mathrm{MPa}$, the impact strength is $W=7,4 \mathrm{~kJ} / \mathrm{m}^{2}$.

Basing on the carried out experimental investigations it was determined (Fig. 2 curve 1), that when DAT content is $q=0,25 \ldots 0,50$ mas.p. in the epoxy oligomer ED - 20, the bending modulus of elasticity value increases from $E=2,9 \mathrm{GPa}$ (for the epoxy matrix) to $E=3,2 \mathrm{GPa}$. It can be assumed, that the increased values of the modulus of elasticity, when unsufficient amount of modifier is introduced, is caused by the available physical-chemical processes, which provide the increase of bending of the epoxy and hydro-oxigen groups of the epoxy oligomer, the modifier and hardener amino groups being available. The maximum on the curve of modulus of elasticity dependence on the modifier content is found, when $\mathrm{C}_{7} \mathrm{H}_{10} \mathrm{~N}_{2}$ content is $q=1,00$ mas.p. Under this content the modulus of elasticity increases till $E=3,4 \mathrm{GPa}$. Amine groups were considered to be additionally more active, which contributes to the improvement of the binder components interaction. When the modifier content increases from $q=1,25$ mas.p. to $q=2,00$ mas.p., the modulus of elasticity decreases, which directly testifies the exceeding carbon content available in the modifier. Such materials are known to possess high rigidity, which provides the mechanical packing of the matrix macroelements.

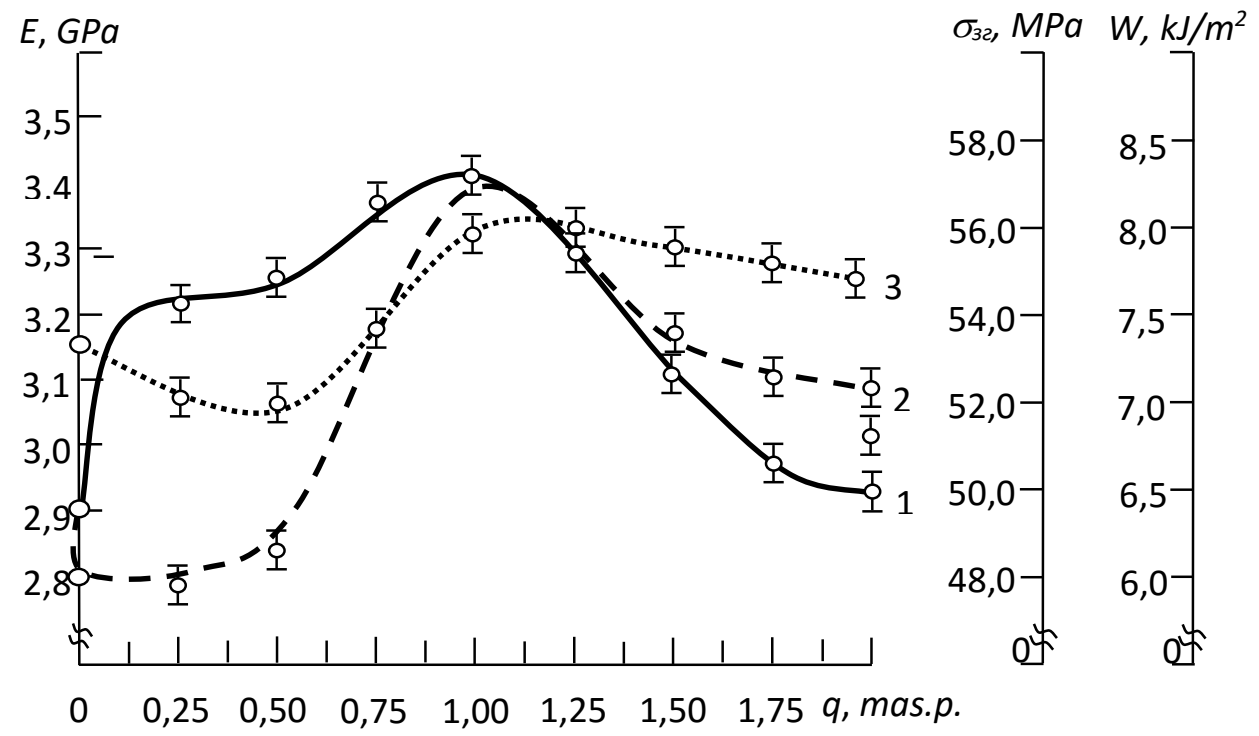

Figure 2. Dependence of physical-mechanical properties and impact strength of the epoxy matrix on the 2,4 - diaminotoluence modifier content: 1 - bending modulus of elasticity $(E) ; 2$ - destructive bending stresses $\left(\sigma_{32}\right) ; 3$ - impact strength $\left(W, k G / m^{2}\right)$

Further the effect of the modifier on the values of the destructive bending stresses was analyzed. It was determined, that the introduction of a modifier in the epoxy binder, its content being unsufficient $q=0,25 \ldots 0,50$ mas.p., does not affect the values of the destructive bending stresses $\left(\sigma_{32}=46,7 \ldots 48,2 \mathrm{MPa}\right)$. The $\mathrm{CM}$ resistance to deformation being not 
Influence of 2,4-diaminotoluene modifier on the physical and mechanical properties of epoxy composite coatings

available under loading, results from the unsufficient amount of the modifier, which usually provides the polimer plasticity. These statements are conformed to the results of investigation of the bending modulus of elasticity, the value of which increases, when the modifier of $q=0,25 \ldots 0,50$ mas.p. content is introduced. Further the increase of the DAT content till $q=1,0$ mas.p. provides forming of CM with the minimum values, of the destructive bending stresses, which equals $\sigma_{32}=57,2 \mathrm{MPa}$. The maximum content of modifier provides the maximum increase of the modulus of elasticity value. Further introduction of the modifier of $q=1,5 \ldots 2,0$ mas.p. content results in the monotonic decrease of the destructive bending stresses $\sigma_{32}=52,0 \ldots 50,2 \mathrm{MPa}$.

At the same time the impact strength of the developed composites was analyzed. The introduction of $q=0,25 \ldots 0,50$ mas.p. content modifier in the epoxy binder was shown not to affect the values of the impact strength $\left(W=6,2 \ldots 6,8 \mathrm{~kJ} / \mathrm{m}^{2}\right)$. Further introduction of modifier causes the decrease of the impact values (Fig. 2, curve 3 ).

Basing on the complex investigations of the physical-mechanical properties it was found, that the optimum content of the modifier in the epoxy binder is $q=1,0$ mas.p. At this content are formed CM, the structure of which provides both plasticity and sufficient rigidity. The combination of properties complex in the developed material will make possible to provide the static and dynamic loading resistance and some extent the impact - nature loadings resistance.

For the detailed investigation of peculiarities of the physical-chemical processes during the structure-forming of modified epoxy composites the IR-spectral comparative analysis of the epoxy matrix structure, as well as the CM of 2,4-diaminotoluence content $q=0,25 \ldots 1,50$ mas.p. was carried out. The analysis of CM IR-spectrums (Fig. 3) at different contents of modifier testifies, that even unsufficient content of modifier $\mathrm{C}_{7} \mathrm{H}_{10} \mathrm{~N}_{2}$ in $\mathrm{CM}$ changes the process of material-structure forming. The numerical IR-spectral analysis made possible to reveal the change of the following parameters: the transmission intensity $(T, \%)$ and the area $(S, \%)$ of the adsorption bands, which specifies different number of chemical bonds in the polimer, as well as the degree of the developed composites binding.

The analysis of IR-spectrums under the wave number $v=582,50 \mathrm{~cm}^{-1}$ and $v=763,81 \mathrm{~cm}^{-1}$ (Table 2) made possible to reveal the displacement of the adsorption band to smaller wave numbers relatively the epoxy matrix. It was considered, that it is caused by the increase of the number of amino groups in the volume unit, thus, the increase of the reaction ability to interact with the segments of epoxy binder. Under such content the materials with high values of the cohesive strength are formed. These statements are confirmed by the results of physical-mechanical investigations.

Displacement of the adsorption bands at $v=763,81 \mathrm{~cm}^{-1}$ (Table 2) on $\Delta v=3,86 \mathrm{~cm}^{-1}$ testifies the adsorption interaction of the epoxy oligomer chain side groups with the molecules of modifier, which provides the growth of the composites mechanical strength, which is conformed with the results of the work [12]. Besides, the maximum values of the relative square of the adsorption bands $(S, \%)$ for $\mathrm{CM}$ with $q=1,0 \ldots 1,5$ mas.p. content of the DAT modifier (Table 2), were found, which were revealed at the wave numbers: $v=840,96 \mathrm{~cm}^{-1}$, $v=1045,42 \mathrm{~cm}^{-1}, v=1188,15 \mathrm{~cm}^{-1}, v=1257,59 \ldots 3047,53 \mathrm{~cm}^{-1}$ (Table 2). Presented results of the IR-spectrum investigations testify the growth of the polimer space lattuce density, although $\mathrm{S}$ is increased and redistribution of the bonds number in the boundary layer is possible, which provides the improvement of the CM properties. 


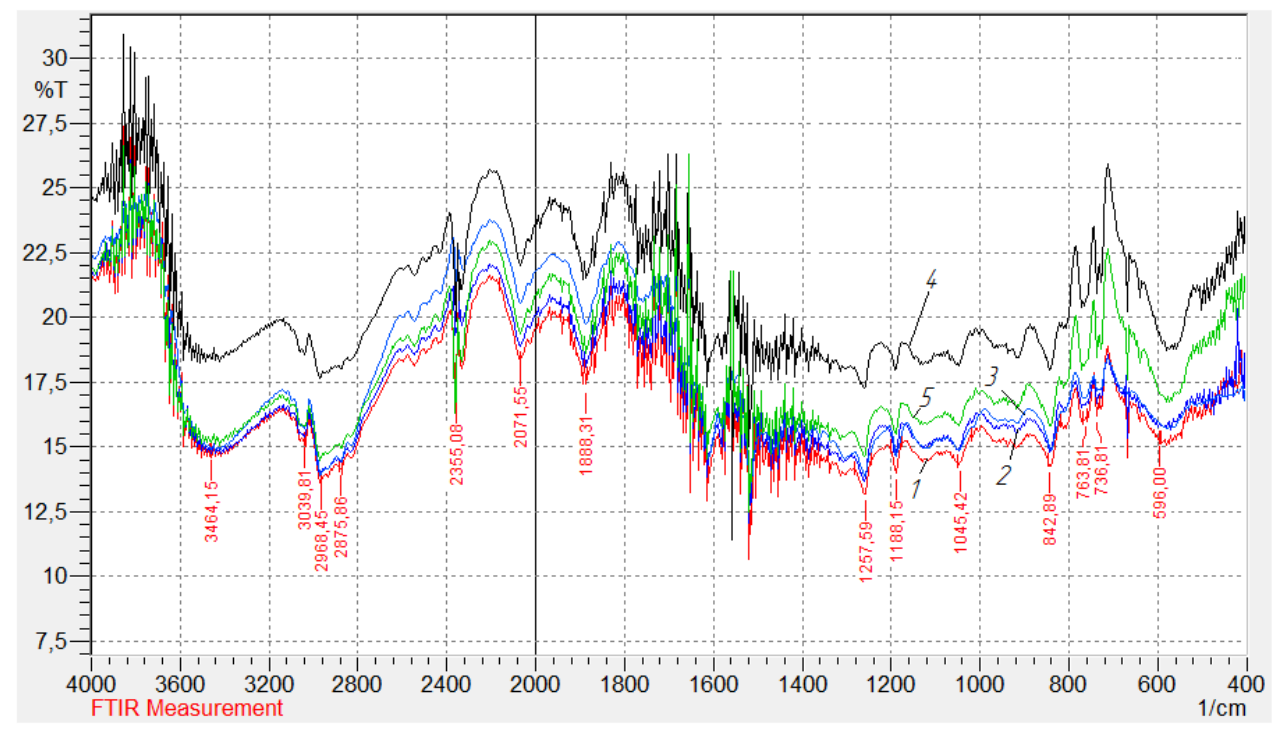

Figure 3. IR-spectral analysis of different 2,4 - diaminotoluence, content composites mass.p.: 1 epoxy matrix; $2-0,25 ; 3-0,50 ; 4-1,0 ; 5-1,5$

Special attention must be paid to the adsorption bands at the wave numbers $v=3464,15 \mathrm{~cm}^{-1}$. Analysis of the paper [1] testifies, that the hydro-oxigen groups (revealed at $v=3047,53 \mathrm{~cm}^{-1}$ ), possessing increased adsorption and catalytic activity, can be blocked by the adsorbed water molecules. The latter being disadvantages for the adhesion of the epoxy resins, preventing the forming of chemical and physical bonds, which causes the decrease of the CM cohesive strength. That is, the least relative square of the adsorption band $S=265,1 \%$ for the CM with DAT $q=1,0$ mas.p. content testifies, that this material is specified by the higher adsorption and catalytic activity, and, thus, the improvement of the cohesive properties. Additional confirmation of it is the greatest (among the investigated materials) relative square of the adsorption band $S=18,3 \%$ (Table 2) for the CM with the DAT content $q=1,0$ mas.p., which specifies the number of $\mathrm{OH}$ groups in the material volume unit.

Thus, according to the results of the IR-spectral analysis it was determined, that sufficient changes in the binder structure take place, when the 2,4-diaminotoluence modifier of $q=1,0 \ldots 1,5$ mas.p. content is introduced. Such materials are specified by the change of parameters $\mathrm{T}, \mathrm{S}$, the values of which are the greatest, as well as the displacement of the maximum of the adsorption bands.

Table 2

Characteristic of adsorption bands according to the composite materials IR-spectrum modified by the 2,4-diaminotoluence

\begin{tabular}{|c|c|c|c|c|c|c|c|c|c|c|c|}
\hline \multirow{2}{*}{\multicolumn{2}{|c|}{ Band properties }} & \multicolumn{10}{|c|}{$\begin{array}{l}\text { IR-spectrums of the epoxy composites with the modifier } \\
\qquad q=0,25 \ldots, 1,5 \text { mas.p. }\end{array}$} \\
\hline & & \multicolumn{2}{|c|}{ Matrix } & \multicolumn{2}{|c|}{0,25} & \multicolumn{2}{|c|}{0,50} & \multicolumn{2}{|c|}{1,0} & \multicolumn{2}{|c|}{1,5} \\
\hline Group & $\begin{array}{c}v, \\
\mathrm{~cm}^{-1}\end{array}$ & $\begin{array}{l}T, \\
\%\end{array}$ & $\begin{array}{l}S, \\
\%\end{array}$ & $\begin{array}{l}T, \\
\%\end{array}$ & $\begin{array}{l}S, \\
\%\end{array}$ & $\begin{array}{l}T, \\
\%\end{array}$ & $\begin{array}{l}S, \\
\%\end{array}$ & $\begin{array}{l}T, \\
\%\end{array}$ & $\begin{array}{l}S, \\
\%\end{array}$ & $\begin{array}{l}T, \\
\%\end{array}$ & $\begin{array}{l}S, \\
\%\end{array}$ \\
\hline 1 & 2 & 3 & 4 & 5 & 6 & 7 & 8 & 9 & 10 & 11 & 12 \\
\hline$-\mathrm{CH}_{2}$-group, parabenzol & 582,50 & 15,7 & 69,8 & 15,79 & 69,8 & 15,9 & 70,3 & $\begin{array}{r}\text { Disple } \\
4 \\
18, \\
\end{array}$ & $\begin{array}{l}\text { emer } \\
= \\
\mathrm{cm}^{-1}\end{array}$ & & $\begin{array}{l}\text { ement } \\
= \\
\mathrm{m}^{-1}\end{array}$ \\
\hline
\end{tabular}


(to be continued)

\begin{tabular}{|c|c|c|c|c|c|c|c|c|c|c|c|}
\hline 1 & 2 & 3 & 4 & 5 & 6 & 7 & 8 & 9 & 10 & 11 & 12 \\
\hline $\begin{array}{l}\text {-NH-, }-\mathrm{CH}-\text { pendulum } \\
\text { vibrations, } \\
\text { primary amines: }-\mathrm{NH}_{2} \text {; } \\
\quad \mathrm{CH}_{2}-\mathrm{NH}_{2}\end{array}$ & 736,81 & 17,1 & 6,3 & 17,1 & 6,3 & 17,8 & 6,5 & 20,8 & 7,6 & 18,4 & 6,6 \\
\hline $\begin{array}{l}\text {-NH-, }-\mathrm{CH}-\text { pendulum } \\
\text { vibrations, } \\
\text { primary amines: }-\mathrm{NH}_{2} \text {; } \\
\quad \mathrm{CH}_{2}-\mathrm{NH}_{2}\end{array}$ & 763,81 & 16,8 & 32,3 & 16,8 & 32,3 & 17,2 & 36,3 & \multicolumn{2}{|c|}{$\begin{array}{c}\text { Displacement } \\
\rightarrow \\
\Delta v= \\
3,86 \mathrm{~cm}^{-1}\end{array}$} & 17,9 & 37,4 \\
\hline $\begin{array}{c}\text {-NH-, }-\mathrm{CH} \text {-pendulum } \\
\text { vibrations, }-\mathrm{C}-\mathrm{C} \text { valency } \\
\text { vibrations, primary amines: } \\
\mathrm{CH}_{2}-\mathrm{NH}_{2}, \mathrm{CH}-\mathrm{NH}_{2}, \\
\text { epoxy-cycle }\end{array}$ & 840,96 & 14,8 & 11,7 & 14,8 & 11,7 & 14,4 & 15,8 & 17,9 & 16,9 & 15,5 & 15,8 \\
\hline \begin{tabular}{|c}
-C-C-, -C-N-, -C-O- valency \\
vibrations, primary amines \\
$\mathrm{CH}^{-\mathrm{NH}_{2}}$, secondary amines \\
$\mathrm{CH}_{2}-\mathrm{NH}-\mathrm{CH}_{2}, 3-\mathrm{d}$ level \\
amines: $\left(\mathrm{CH}_{2}\right)_{3} \mathrm{~N}$, amine \\
group -CO-NH${ }_{2}$ \\
\end{tabular} & 1045,42 & 14,9 & 12,7 & 14,9 & 12,8 & 14,7 & 13,7 & 18,1 & 14,1 & 15,8 & 13,7 \\
\hline $\begin{array}{c}\mathrm{C}-\mathrm{C}-,-\mathrm{C}-\mathrm{N}-,-\mathrm{C}-\mathrm{O}-\text { valency } \\
\text { vibrations, epoxy cycle, } \\
\text { secondary amines: } \mathrm{CH}_{2}-\mathrm{NH}- \\
\mathrm{CH}_{2} \text {, primary amines: } \\
\mathrm{CH}_{2}-\mathrm{NH}_{2}\end{array}$ & 1188,15 & 14,6 & 11,3 & 14,6 & 11,3 & 15,0 & 13,3 & 17,9 & 16,8 & 15,5 & 14,3 \\
\hline $\begin{array}{c}-\mathrm{OH}-\text { destructive vibrations, } \\
\text {-C-N-, -C-O- valency } \\
\text { vibrations, epoxy cycle, } \\
\text { primary amines: }-\mathrm{NH}_{2}\end{array}$ & 1257,59 & 13,9 & 18,7 & 13,9 & 18,7 & 14,1 & 19,0 & 17,2 & 20,1 & 14,6 & 19,7 \\
\hline $\begin{array}{c}\text { Epoxy group valency } \\
\text { vibrations }\end{array}$ & 1886,38 & 18,7 & 47,6 & 19,7 & 47,6 & 18,6 & 58,3 & 21,1 & 68,8 & 18,6 & 58,3 \\
\hline$-\mathrm{C} \equiv \mathrm{N}-$ valency vibrations & 2063,83 & 20,5 & 39,3 & 20,7 & 40,0 & 19,1 & 43,9 & 22,0 & 68,4 & 19,4 & 48,9 \\
\hline $\begin{array}{c}-\mathrm{CH}-\text { valency vibrations, } \\
-\mathrm{OH}\end{array}$ & 3047,53 & 13,8 & 15,5 & 13,8 & 15,5 & 15,3 & 17,9 & 18,7 & 18,3 & 15,7 & 17,9 \\
\hline $\begin{array}{l}\text {-NH- valency vibrations, } \\
\text { sorbed } \mathrm{H}_{2} \mathrm{O}\end{array}$ & 3464,15 & 14,9 & 321,4 & 14,9 & 321,4 & 18,4 & 321,4 & 18,4 & 265,1 & 18,4 & 321,4 \\
\hline
\end{tabular}


Conclusions. In the paper the optimum content of the 2,4 - diaminotoluence modifier for forming materials and protective coatings with the improved cohesive properties was determined, which makes possible to provide long-term operation of the surface and machine parts of the manufacturing equipment. It was confirmed:

- to form coatings, providing improved mechanical properties it is worth using composites containing 2,4 - diaminotoluence modifier of $q=1,0$ mas.p. content in 100 mas.p. ED-20 epoxy oligomer and 10 mas.p. hardener PEPA. These composites possess such properties: the bending modulus of elasticity is $E=3,4 \mathrm{GPa}$, destructive bending stresses are $\sigma_{32}=57,2 \mathrm{MPa}$, impact strength is $W=7,9 \mathrm{~kJ} / \mathrm{m}^{2}$;

- taking advantage of the IR-spectral analysis the process of physical-chemical interaction of the modifier with the epoxy binder macromolecules and segments were investigated. The adsorption interaction of the chain side groups of the epoxy oligomer with the modifier molecules of $q=1,0 \ldots 1,5$ mas.p. content, which is specified by the displacement of the adsorption bands at the wave frequencies $v=582,50 \mathrm{~cm}^{-1}$ and $v=763,81 \mathrm{~cm}^{-1}$, was revealed. Besides, it was determined, that the composite material of the 2,4 - diaminotoluence content $q=1,0$ mas. $p$. possess increased adsorption and catalytic activity, although the square of the adsorption band at the wave number $v=3464,15 \mathrm{~cm}^{-1}$ is of the smallest value and equals $S=265,1 \%$. It testifies unsufficient blocking of $\mathrm{OH}$-groups by the sorbed water molecules. Thus, the obtained results of the IR-spectral analysis confirm the effective application of the modifier of the optimal content, which provides the increase of the composites mechanical strength.

\section{References}

1. Buketov A.V., Stukhliak P.D., Chykhira I.V. Vlastyvosti modyfikovanykh ultrazvukom epoksyplastiv: monohrafiia. Ternopil, Krok, 2011, 201 p. [In Ukrainian].

2. Buketov A.V, Akymov A.V., Sapronov A.A. Polymerkompozytnie zashchytnie ohneupornie pokrityia: monohrafiia. Kherson, KhHMA, 2017, 172 p.

3. Buketov A.V., Sapronov O.O., Brailo M.V., Buketova N.M., Dulebová L., Aleksenko V.L., Yatsiuk V.M. Vidnovlennia zasobiv transportu fulerenovmisnymy epoksykompozytamy. Kherson, KhDMA, 2018, $164 \mathrm{p}$.

4. Buketov A., Maruschak P., Sapronov O., Zinchenko D., Yatsyuk V., Panin S. Enhancing performance characteristics of equipment of sea and river transport by using epoxy composites. Transport, 2016, Vol. 31 (3), pp. $333-342$.

5. Ben A., Sapronov O., Buketova N., Yatsiuk V. Doslidzhennia vplyvu modyfikatora 3,31 - (1,4 - fenilen) bis (2 - khloropropionitrylu) na vlastyvosti epoksydnoi matrytsi. Fizyko-khimichna mekhanika materialiv, 2014, Vol. 10, pp. $341-346$.

6. Buketov A.V., Sapronov A.A., Yatsiuk V.N., Hryshchuk B.D., Baranovskyi V.S. Yssledovanye vlyianyia 1,4 - bys (N,N dymetyldytyokarbamato) benzena na mekhanycheskye svoistva epoksydnoi matryts. Plastycheskye massi, 2014, No. $3-4$, pp. $26-34$.

7. Buketov A.V., Sapronov O.O., Yatsiuk V.M., Skyrdenko V.O. Yssledovanye vlyianyia modyfykatora 4,4 - metylenbys $(4,1$ - fenylen) bys (N,N - dyetyldytyokarbamata) na strukturu y svoistva epoksydnoi matrytsi. Plastycheskye massi, 2014, No. $7-8$, pp. $9-16$.

8. Buketov A.V., Braylo N.V., Sapronov O.O., Yatsiuk V.N., Akymov A.V. Yssledovanye vlyianyia modyfykatora 2 - metyl - 2 - tyotsyanato $-3-(4-$ tyotsyanatofenyl $)$ propyoamyda na strukturu y svoistva epoksydnoi matrytsi. Mekhanyka kompozytsyonnikh materyalov y konstruktsyi, 2014, No. 4 (20), pp. $539-554$.

9. Khodakovskyi O.V., Amelin M.Yu., Buketova N.M., Sapronov O.O., Yatsiuk V.M. Doslidzhennia fizyko-mekhanichnykh vlastyvostei modyfikovanykh paraaminoazobenzolom epoksydnykh kompozytiv dlia remontu zasobiv transportu. Naukovyi visnyk KhDMA, 2017, No. 1 (16), pp. $113-120$. 
Influence of 2,4-diaminotoluene modifier on the physical and mechanical properties of epoxy composite coatings

10. Nakamoto K. YK-spektri y spektri KR neorhanycheskykh y koordynatsyonnikh soedynenyi: per. s anhl. Moscow, Myr, 1991, 536 p.

11. Safulyn R.S. Neorhanycheskye kompozytsyonnie materyali. Moscow, Khymyia, 1983, 304 p.

12. Buketov A.V., Sapronov A.A., Buketova N.N., Brailo M.V., Marushak P.O., Panin S.V., Amelin M.Yu. Impact toughness of nanocomposite materials filled with fullerene C60 particles. Composites, Mechanics, Computations, Applications. An International Journal, 2018, Vol. 9 (2), pp. 141 - 161.

\section{Список використаної літератури}

1. Букетов, А.В.Властивості модифікованих ультразвуком епоксипластів: монографія [Текст] / А.В. Букетов, П.Д. Стухляк, І.В. Чихіра. - Тернопіль : Крок, 2011. - 201 с.

2. Букетов, А.В. Полимеркомпозитные защитные огнеупорные покрытия: монография [Текст] / А.В. Букетов, А.В. Акимов, А.А. Сапронов. - Херсон : ХГМА, 2017. - 172 с.

3. Відновлення засобів транспорту фулереновмісними епоксикомпозитами [Текст] / А.В. Букетов, О.О. Сапронов, М.В. Браїло, Н.М. Букетова, L. Dulebová, В.Л. Алексенко, В.М. Яцюк. - Херсон : ХДМА, 2018. - $164 \mathrm{c}$.

4. Enhancing performance characteristics of equipment of sea and river transport by using epoxy composites [Text] / A. Buketov, P. Maruschak, O. Sapronov, D. Zinchenko, V. Yatsyuk, S. Panin // Transport. 2016. - Vol. 31 (3). - Р. 333 - 342.

5. Дослідження впливу модифікатора 3,31 - (1,4 - фенілен) біс (2 - хлоропропіонітрилу) на властивості епоксидної матриці [Текст] / А. Бень, О. Сапронов, Н. Букетова, В. Яцюк // Фізикохімічна механіка матеріалів. - 2014. - Спец. вип. № 10. - С. 341 - 346.

6. Исследование влияния 1,4 - бис (N,N диметилдитиокарбамата) бензена на механические свойства эпоксидной матрицы [Текст] / А.В. Букетов, А.А. Сапронов, В.Н. Яцюк, Б.Д. Грищук, В.С Барановський // Пластические массы. - 2014. - № 3 - 4. - С. 26 - 34.

7. Исследование влияния модификатора 4,4' - метиленбис $(4,1$ - фенилен) бис (N, N диэтилдитиокарбамата) на структуру и свойства эпоксидной матрицы [Текст] / А.В. Букетов, О.О. Сапронов, В.М. Яцюк, В.О. Скирденко // Пластические массы. - 2014. - № 7 - 8. - С. 9 - 16.

8. Исследование влияния модификатора 2 - метил -2 - тиоцианато - 3 - (4 - тиоцианатофенил) пропиоамида на структуру и свойства эпоксидной матрицы [Текст] / А.В. Букетов, Н.В. Браило, О.О. Сапронов, В.Н. Яцюк, А.В. Акимов // Механика композиционных материалов и конструкцій. - 2014. - № 4 (20). - С. 539 - 554.

9. Дослідження фізико-механічних властивостей модифікованих парааміноазобензолом епоксидних композитів для ремонту засобів транспорту [Текст] / О.В. Ходаковський, М.Ю. Амелін, Н.М. Букетова, О.О. Сапронов, В.М. Яцюк // Науковий вісник ХДМА. - 2017. - № 1 (16). - С. 113 -120 .

10. Накамото, К. ИК-спектры и спектры КР неорганических и координационных соединений: пер. с англ. [Текст] / К. Накамото. - М. : Мир, 1991. - 536 с.

11. Сафулин, Р.С. Неорганические композиционные материалы [Текст] / Р.С. Сафулин. - М. : Химия, 1983. - 304 c.

12. Impact toughness of nanocomposite materials filled with fullerene $\mathrm{C}_{60}$ particles [Text] / A.V. Buketov, A.A. Sapronov, N.N. Buketova, M.V. Brailo, P.O. Marushak, S.V. Panin, M.Yu. Amelin // Composites: Mechanics, Computations, Applications. An International Journal. - 2018. - Vol. 9 (2). - P. 141 - 161. 


\title{
ВПЛИВ МОДИФІКАТОРА 2,4-ДІАМІНОТОЛУЕНУ НА ФІЗИКО- МЕХАНІЧНІ ВЛАСТИВОСТІ ЕПОКСИДНИХ КОМПОЗИТНИХ ПОКРИТТІВ
}

\author{
Данило Стухляк'; Анна Сапронова ${ }^{2}$; Віталій Яцюк³; Богдан Грищук ${ }^{4}$ \\ ${ }^{1}$ Тернопільський нащіональний технічний університет імені Івана Пулюя, \\ Тернопіль, Україна \\ ${ }^{2}$ Херсонська державна морська академія, Херсон, Украӥна \\ ${ }^{3}$ Тернопільський науково-дослідний експертно-криміналістичний центр \\ МВС Украӥни, Тернопіль, Украӥна \\ ${ }^{4}$ Тернопільський національний педагогічний університет імені Володимира \\ Гнатюка, Тернопіль, Україна
}

\begin{abstract}
Резюме. Для формування композитного матеріалу з підвищеними показниками фізикомеханічних властивостей використано епоксидний діановий олігомер ЕД-20, твердник поліетиленполіамін ПЕПА і модифікатор 2,4 - діамінотолуен. Дана композиція може формуватися за кімнатних температур. Досліджено залежність вмісту 2,4 - діамінотолуену на фізико-механічні властивості епоксидних композитів. Модифікатор вводили у зв'язувач за вмісту від 0,25 до 2,00 таs.p. на 100 mas.p. зв'язувача. Модифікатор $\mathrm{C}_{7} \mathrm{H}_{12} \mathrm{~N}_{2}$ розчинний у метанолі, етанолі, ацетоні, етилацетоні, малорозчинний у воді. Для формування захисного покриття із поліпшеними когезійними властивостями оптимальний вміст модифікатора становить $q=1,0$ mas.p. на 100 mas.p. епоксидного олігомера ЕД-20, щзо забезпечує підвищення здатності розробленого матеріалу чинити опір статичним, динамічним, а також навантаженням ударного характеру. За оптимального вмісту модифікатора у композиті ударна в'язкість становить $W=7,9 \mathrm{~kJ} / \mathrm{m}^{2}$, модуль пружності при згинанні - 3,4 GPa, руйнівне напруження при згинанні - $\sigma_{32}=57,2 \mathrm{MPa}$. Методом ІЧ-спектрального аналізу виявлено адсорбиійну $i$ каталітичну активність модифікатора, щчо забезпечує взаємодію з боковими групами ланцюга епоксидного олігомера, внаслідок чого зростає когезійна міцність матеріалів. ІЧ-спектроскопією встановлено зміну інтенсивності пропускання і площі поглинання. Композитний матеріал із умістом модифікатора $q=1,0 \ldots 1,5$ mas.p., на 100 mas.p. зв'язувача характеризується адсорбиійною й каталітичною активністю, позаяк площуа смуги поглинання при хвильовому числі $v=3464,15 \mathrm{~cm}^{-1} \mathrm{cяzа \epsilon}$ найменшого значення і становить $-S=265,1 \%$. Це вказує на незначне блокування ОН-груп сорбованими молекулами води. Вказані прочеси пов'язані з збільшенням аміногруп в одиниці об'єму зв'язувача за рахунок збільшення реакційної здатності до взаємодї із сегментами макромолекул епоксидної матриці. Таким чином, доведено ефективність використання даного модифікатора для створення модифікованого зв'язувача епоксидних композитів, щуо призначені для формування покриттів.
\end{abstract}

Ключові слова: епоксидний композит, руйнівні напруження при згинанні, модуль пружності, ударна в'язкість, ІЧ-спектральний аналіз.

Отримано 28.06.2018 